\title{
LEI BRASILEIRA DE INCLUSÃO E A TEORIA DA INCAPACIDADE: OS DESAFIOS INTERPRETATIVOS PARA A NOVA LEGISLAÇÃO CIVIL
}

\author{
BRAZILIAN LAW OF INCLUSION AND INCAPACITY THEORY: THE \\ INTERPRETATIVE CHALLENGES FOR THE NEW CIVIL LEGISLATION
}

\author{
Rafael Lamera Giesta Cabral'
}

\begin{abstract}
RESUMO: Após longa tramitaçăo no Congresso brasileiro, em 2015, a Lei Brasileira de Inclusăo tornou-se realidade. Um dos grandes destaques da legislaçăo foi estabelecer que a deficiência deixa de ser um atributo da pessoa, nâo mais considerada, para efeitos civis, como uma condiçâo estática e biológica da pessoa. Assim, o impedimento de longo prazo de natureza física, mental, intelectual ou sensorial passou a ser compreendido como resultado da interaçóes das barreiras existentes que possam obstruir sua participaçăo plena e efetiva na sociedade em igualdade de condiçóes com as demais pessoas, conforme dispóe a Lei no 13.146/2015. O objetivo deste trabalho é identificar em quais medidas a lei de inclusâo interage com a teoria da incapacidade e impóe novos desafios para construir o instituto da Tomada de Decisăo Apoiada. Para que o objetivo seja alcançado, a pesquisa levanta nos referenciais teóricos, jurisprudenciais e históricos os limites e possibilidades que incorporaram nas legislaçōes civis, a inclusâo de deficientes. Até o presente momento, a lei de inclusâo impôs alteraçóes que a própria interpretaçáo jurisprudencial ainda nâo foi capaz de resolver, principalmente, pela ausência de diálgo legislativo entre a Lei Brasileira de Inclusăo, que alterou o Código Civil brasileiro, e o Novo Código de Processo Civil, que manteve sua estrutura processual sem levar em consideraçâo parte das inovaçôes da lei de inclusâo.
\end{abstract}

PALAVRAS-CHAVE: Lei Brasileira de Inclusăo; Teoria da incapacidade civil; Tomada de Decisāo Apoiada.

ABSTRACT: After a long process in the Brazilian Congress, in 2015, the Brazilian Inclusion Law became a reality. One of the great highlights of the legislation was to establish that disability ceases to be an attribute of the person. The disability is no longer considered as a static and biological condition of the person for civil effects. Thus, the long-term impediment of a physical, mental, intellectual or sensorial nature came to be understood as a result of the interactions of existing barriers that may obstruct their full and effective participation in society on an equal basis with other persons, as provided by Law № 13,146 / 2015. The objective of this paper is to identify in which basis the law of inclusion interacts with the theory of incapacity and imposes new challenges to build the institute of Supported Decision Making. In order to achieve the objective, the research raise the limits and possibilities that incorporate in the civil legislation, the inclusion of disabled people in theoretical, jurisprudential

Doutor em Direito, Estado e Constituiçăo pela Universidade de Brasília, UnB. Mestre em Ciência Política pela Universidade Federal de Sáo Carlos, UFSCar. Bacharel em Direito pela Universidade Estadual de Mato Grosso do Sul, UEMS. rafaelcabral@ufersa.edu.br 
and historical references. Until today, the inclusion law has imposed changes that the jurisprudential interpretation itself has not been able to solve, mainly, by the lack of legislative dialogue between the Brazilian Inclusion Law, which amended the Brazilian Civil Code, and the New Code of Procedure Civil, which maintained its procedural structure without considering part of the innovations of the law of inclusion.

KEY WORDS: Brazilian Inclusion Law; Theory of civil capacity; Decision Making Supported.

\section{INTRODUÇÃO}

Desde 2002, quando o Código Civil brasileiro entrou em vigor, a teoria da incapacidade civil era objeto de tensâo que envolvia diretamente a impossibilidade de algumas pessoas exercerem pessoalmente os atos da vida civil.

Pelo regramento originário, (i) os menores de dezesseis anos, (ii) os que, por enfermidade ou deficiência mental, nâo tiverem o necessário discernimento para a prática desses atos e (iii) os que, mesmo por causa transitória, năo puderem exprimir sua vontade eram considerados absolutamente incapazes para o exercício pessoal dos atos da vida civil.

Em 21 de dezembro de 2006, o país recebia uma proposta legislativa que foi construída sob muitos aspectos e com ampla participaçăo da sociedade civil. ${ }^{2}$ Transformada em projeto de lei n. ${ }^{\circ}$ 7.699/2006, a proposta agrupou outros projetos de lei em curso no Congresso Nacional e após longo processo de tramitaçăo, tornou-se lei ordinária em 06 de julho de 2015 (Lei n. ${ }^{\circ}$ 13.146), instituindo no país a Lei Brasileira de Inclusâo da Pessoa com Deficiência, também reconhecido como Estatuto da Pessoa com Deficiência.

Com vacatio legis de seis meses, a lei entrou em vigor no início de janeiro de 2016, alterando significativamente a teoria da incapacidade civil. Em um primeiro momento, a inovaçăo pode ser observada com a nova redaçăo dada pela lei ao artigo 3o do Código Civil: "Sâo absolutamente incapazes de exercer pessoalmente os atos da vida civil os menores de dezesseis anos".

Com a nova orientaçâo, a lei revogou os demais dispositivos previstos anteriormente, excluindo do rol da incapacidade absoluta, os que, por enfermidade ou deficiência mental, năo tiverem o necessário discernimento para a prática desses atos e os que, mesmo por causa transitória, nâo puderem exprimir sua vontade. Assim, existe uma única forma de se reconhecer a incapacidade absoluta para atuar nos atos da vida civil: os menores de 16 anos.

Sem as demais possibilidades de incapacidade, aventou-se entre os estudiosos dúvidas sobre o real impacto sobre o instituto da curatela e por consequência, da interdiçăo, com possível reduçâo ou até mesmo extinçăo desta modalidade. No entanto, a curatela ainda pode ser manejada para as situaçóes de incapacidade relativa para os atos da vida civil dos maiores de dezoito anos.

O rol dos relativamente incapazes também sofreu alteraçóes com o advento da Lei Brasileira de Inclusăo. Pelo conceito antigo, os deficientes mentais que tinham

Em consulta ao histórico da proposta de lei foi possível constatar que além das audiências públicas e espaços de diálogos entre inúmeros atores, a proposta ficou disponível para consulta, opiniōes e sugestốes no portal E-Democracia, da Câmara dos Deputados, por longo período de tempo. 
discernimento reduzido e os excepcionais, sem desenvolvimento mental completo, foram excluídos deste rol de incapacidade relativa. Por outro lado, aqueles que, por causa transitória náo pudessem exprimir sua vontade (antes, absolutamente incapazes), passaram a compor o rol da incapacidade relativa.

Essas alteraçôes legislativas estăo ligadas diretamente às açôes de inclusăo que movem as principais instituiçôes de promoçăo aos direitos das pessoas com deficiência. Em 25 de agosto de 2009, o presidente Luíz Inácio Lula da Silva promulgou o decreto n. 6.949, que incluiu no ordenamento constitucional brasileiro a Convençáo Internacional sobre os Direitos das Pessoas com Deficiência e seu protocolo facultativo, assinados em Nova Iorque, em 30 de março de 2007.

No plano internacional, a convençăo tinha como escopo promover, proteger e assegurar o exercício pleno e equitativo de todos os direitos humanos e liberdades fundamentais por todas as pessoas com deficiência e promover o respeito pela sua dignidade inerente. Com isso, a convençăo reconheceu como pessoas com deficiências aquelas que têm impedimentos de longo prazo de natureza física, mental, intelectual ou sensorial, os quais, em interaçấo com diversas barreiras, podem obstruir sua participaçáo plena e efetiva na sociedade em igualdades de condiçôes com as demais pessoas.

Assim, o destaque modificativo no direito pátrio reconhece que a deficiência nâo afeta a plena capacidade civil da pessoa, e naquelas situaçôes em que, eventualmente, por se tratar de negócios jurídicos mais complexos e de cunho patrimonial, necessitem de apoio, a legislaçấo incluiu no instituto da tomada de decisấo apoiada.

Embora a nova legislaçâo tenha alterado o Código Civil para reconhecer que nâo há incapacidade absoluta em decorrência de deficiências, a forma como as alteraçóes ocorreram trouxeram dúvidas de grande porte, principalmente pelo atropelamento de uma norma jurídica por outra em decorrência da Lei de Inclusăo da Pessoa com Deficiência e o Novo Código de Processo Civil.

Lançando máo de pesquisa bibliográfica em cotejo com as jurisprudências que foram elaboradas a partir do impacto da nova legislaçăo, busca-se neste artigo identificar em quais medidas a lei de inclusâo da pessoa com deficiência interage e modifica a teoria da incapacidade civil e impóe novos desafios para construir e efetivar o instituto da tomada de decisâo apoiada, principalmente, a partir do atropelo jurídico ocorrido entre a vigência das leis n. ${ }^{\circ}$ 13.146/2015 (Lei de Inclusăo) e n. ${ }^{\circ}$ 13.105/2015 (Novo Código de Processo Civil).

O texto será dividido em duas seçōes. Na primeira, buscar-se-á demonstrar o desenvolvimento histórico no âmbito internacional da Convençăo Internacional sobre os Direitos das Pessoas com Deficiência e, na segunda seçăo, analisar-se-á o impacto da convençâo a partir de sua inclusăo no ordenamento jurídico brasileiro, com vistas a problematizar os limites e as possibilidades decorrentes da alteraçăo.

\section{CONVENÇÃO INTERNACIONAL SOBRE OS DIREITOS DAS PESSOAS COM DEFICIÊNCIA}

Em 13 de dezembro de 2006, em homenagem ao 58. aniversário da Declaraçâo Universal dos Direitos Humanos, a Assembleia Geral da Organizaçăo das Naçôes 
Unidas (ONU) homologava uma norma internacional vinculante para promover, proteger e assegurar às pessoas com deficiência o exercício pleno e equitativo de direitos. Tratava-se da convençâo internacional sobre direitos das pessoas com deficiência.

O Brasil ratificou a convençăo em 20 de março de 2007 e após os trâmites constitucionais internos, o Congresso Nacional aprovou, por meio do Decreto Legislativo n. ${ }^{\circ}$ 186, de 09 de julho de 2008, o texto da convençấo. Em 25 de agosto de 2009, a presidência da República promulgou a convençâo, incorporando seus dispositivos ao ordenamento constitucional brasileiro.

Na prática, a convençâo tem se tornado um marco histórico nas açōes de proteçăo às pessoas com deficiência. Segundo dados do Censo brasileiro de 2000, cerca de 14,5\% da populaçăo brasileira possui alguma limitaçăo funcional. Desde 1988, com a promulgaçấo da Constituiçăo Federal, algumas medidas legislativas foram lançadas para instituir políticas que culminaram em leis como a n.․ 7.853, de 24 de outubro de $1989,{ }^{3}$ n.. 10.048, de 08 de novembro de $2000,{ }^{4}$ n..$^{-10.098}$, de 19 de dezembro de $2000^{5}$ e o decreto n. -5.296 , de 02 de dezembro de $2004{ }^{6}$

Em que pese o lento esforço legislativo observado no país, a condiçăo de deficiente sempre impôs limites ao exercício pessoal de direitos e a convençâo tem um bom ponto de partida ao reconhecer na alínea $f$ que a deficiência é um conceito em evoluçăo, principalmente por constatar que a deficiência resulta da interaçăo entre pessoas com deficiência e as barreiras devidas às atitudes e ao ambiente que impedem a plena e efetiva participaçấo dessas pessoas na sociedade em igualdade de oportunidades com as demais pessoas.

A concepçăo de deficiência como um conceito em evoluçăo permite uma interpretaçăo aberta sobre a diversidade das pessoas com deficiência (inclusive daqueles que requerem maior apoio) que podem se expandir ou năo frente às novas barreiras causadas em contextos específicos, pois ao vislumbrar impedimentos que dificultem a participaçâo dessas pessoas na sociedade em igualdade, cria mecanismos e alternativas para a inclusáo com autonomia, independência individual e liberdade para fazer as próprias escolhas.

A convençăo, mesmo reconhecendo a condiçăo de conceito em evoluçăo, avançou em firmar um parâmetro conceitual ao considerar que pessoas com deficiência sâo aquelas que têm impedimentos de longo prazo de natureza física, mental, intelectual ou sensorial, os quais, em interaçăo com diversas barreiras, podem obstruir sua participaçăo plena e efetiva na sociedade em igualdades de condiçôes com as demais pessoas.

De forma clara, o conceito exclui da pessoa a deficiência para remetê-la para o meio em que vive a pessoa. $\mathrm{O}$ deficiente náo porta deficiência e impacta na forma como as

3 Esta lei dispôs sobre o apoio às pessoas com deficiência, sua integraçăo social, sobre a coordenadoria nacional para integraçăo da pessoa com deficiência (CORDE) e instituiu a tutela jurisdicional de interesses coletivos ou difusos dessas pessoas, com regras para atuaçâo do Ministério Público e definiçáo de crimes.

4 Esta lei regulamentou o rol de pessoas que passaram a ter atendimentos prioritários em repartiçóes públicas e empresas concessionárias de serviços públicos.

5 Esta lei estabeleceu normas gerais e critérios básicos para a promoçáo da acessibilidade das pessoas com deficiências ou com mobilidade reduzida.

$6 \quad$ O decreto instituiu normas gerais e criou critérios básicos para a promoçâo de acessibilidade das pessoas com deficiências ou com mobilidade reduzida. 
definiçóes da pessoa com deficiência serăo revisadas nos Estados Partes que ratificaram a convençấo. Segundo Gaburri (2016), no Brasil, por exemplo, dois modelos eram utilizados no ordenamento jurídico para definir se uma pessoa pode ser considerada com deficiência ou năo. Tratava-se do modelo médico, iniciado na década de 1960, referenciado pelo paradigma de serviços como escolas especiais, entidades assistenciais e centros de reabilitaçăo e o modelo social, que visava a inclusăo social, com esforços mútuos para a inserçăo social da pessoa com deficiência.

O regramento da convençâo segue o modelo social, principalmente quando afirma que a avaliaçăo da deficiência, quando necessária, será biopsicossocial, realizada por equipe multiprofissional e interdisciplinar para considerar os impedimentos nas funçôes e nas estruturas do corpo, os fatores socioambientais, psicológicos e pessoais, a limitaçâo no desempenho de atividades e a restriçăo de participaçăo.

Conforme demonstra Izabel Maria Madeira de Loureiro Maior, em apresentaçăo ao livro editado pela Secretaria Especial de Direitos Humanos da Presidência da República sobre a convençāo (BRASIL, 2008, p. 21):

a ONU abriu suas portas, pela primeira vez para a sociedade civil organizada, na elaboraçăo, em tempo recorde, da Convençăo sobre Direitos das Pessoas com Deficiência (2002 a 2006). [...] A ONU mudou antes e transformou-se ainda mais, com o êxito das negociaçōes maduras, sensatas e progressistas da convençăo [...].

Essas transformaçóes podem ser observadas a partir dos princípios que inspiram a convençăo (artigo terceiro): i) o respeito pela dignidade inerente, a autonomia individual, inclusive a liberdade de fazer as próprias escolhas, e a independência das pessoas; ii) a năo-discriminaçáo; iii) a plena e efetiva participaçăo e inclusăo na sociedade; iv) o respeito pela diferença e pela aceitaçấo das pessoas com deficiência como parte da diversidade humana e da humanidade; v) a igualdade de oportunidades; vi) a acessibilidade; vii) a igualdade entre o homem e a mulher; viii) o respeito pelo desenvolvimento das capacidades das crianças com deficiência e pelo direito das crianças com deficiência de preservar sua identidade.

Esses princípios foram incorporados nos cinquenta artigos que compóem o texto da convençăo internacional e em decorrência desses princípios, os Estados Partes se comprometem a adotar todas as medidas necessárias, inclusive legislativa, para modificar ou revogar leis, regulamentos, costumes e práticas vigentes, que constituírem discriminaçấo contra pessoas com deficiência.

No Brasil, desde 2004, os tratados e convençôes internacionais sobre direitos humanos que forem aprovados pelo Congresso Nacional passam a ser equivalentes às emendas constitucionais. Na prática, desde 2009 a convençâo internacional já havia sido incorporada no ordenamento jurídico nacional. No entanto, a grande modificaçăo legislativa ocorreu com a promulgaçăo da lei n.. 13.146, de 06 de julho de 2015, que instituiu a Lei Brasileira de Inclusăo da Pessoa com Deficiência (Estatuto da Pessoa com Deficiência).

Inspirada nos termos da convençăo, a lei nacional incorporou um conjunto significativo de açóes de promoçăo e proteçâo aos direitos das pessoas com deficiência, principalmente, ao estabelecer marcos, conceitos e orientaçóes educativas para as geraçôes presentes e futuras. 
O artigo sexto da lei n. 13.146 destaca que a deficiência năo afeta a capacidade civil da pessoa, inclusive para a constituiçăo de família pelo casamento ou uniâo estável, para o exercício dos direitos sexuais e reprodutivos, exercício do direito de decidir sobre o número de filhos e de ter acesso a informaçóes adequadas sobre reproduçăo e planejamento familiar; conservar sua fertilidade, sendo vedada a esterilizaçăo compulsória; exercer o direito à família e à convivência familiar e comunitária e exercer o direito à guarda, à tutela, à curatela e à adoçăo, como adotante ou adotando, em igualdade de oportunidades com as demais pessoas.

A seguir, apontar-se-á o impacto da lei de inclusâo da pessoa com deficiência frente a teoria da incapacidade civil e os desafios do instituto tomada de decisáo apoiada.

\section{A INCAPACIDADE CIVIL E O INSTITUTO DA TOMADA DE DECISÃO APOIADA NO CÓDIGO CIVIL}

A partir do momento que a lei n.o 13.146/2015 estabeleceu que a deficiência năo afeta a plena capacidade civil da pessoa, a teoria da incapacidade civil se alterou completamente e repercutiu em vários ramos do direito civil brasileiro.

A inovaçăo privilegia a tutela da dignidade-liberdade das pessoas com deficiência em detrimento do modelo de que pessoas com deficiência deveriam ser protegidas por serem vulneráveis.

Nessa perspectiva, a alteraçăo legislativa é um desdobramento dos comandos estabelecidos tanto na Convençăo quanto no Estatuto da Pessoa com Deficiência que impóe ao Estado, sociedade e família o dever de assegurar à pessoa com deficiência, com prioridade, a efetivaçăo dos direitos referentes à vida, à saúde, à sexualidade, à paternidade e à maternidade, à alimentaçáo, à habitaçáo, à educaçáo, à profissionalizaçấo, ao trabalho, à previdência social, à habilitaçâo e à reabilitaçâo litaçao, ao transporte, à acessibilidade, à cultura, ao desporto, ao turismo, ao lazer, à informaçấ, à comunicaçăo, aos avanços científicos e tecnológicos, à dignidade, ao respeito, à liberdade, à convivência familiar e comunitária, entre outros decorrentes da Constituiçâo Federal, da Convençáo sobre os direitos das pessoas com deficiência e seu protocolo facultativo e das leis e de outras normas que garantam seu bem-estar pessoal, social e econômico (artigo oitavo, da Lei n.․⒔146/2015).

Ao colocar em destaque a igualdade, o Estatuto revogou, no art. 123, os incisos I, II e III do artigo 3. do Código Civil brasileiro, para excluir do rol da incapacidade civil os que, por enfermidade ou deficiência mental, náo tiverem o necessário discernimento para a prática desses atos e os que, mesmo por causa transitória, nâo puderem exprimir sua vontade.

Dentro desta lógica, revogou-se também o impedimento de deficientes, cegos e surdos atuarem como testemunhas. Revogou a proibiçâo de casamento por "enfermo mental sem o necessário discernimento para os atos da vida civil" (artigo 1.548, I, Código Civil), bem como excluiu do rol de erro essencial sobre a pessoa do outro cônjuge a "ignorância, anterior ao casamento, de doença mental grave que, por sua natureza, torne insuportável a vida em comum ao cônjuge enganado" (artigo 1.557, IV, Código Civil).

Segundo Ana Paula Crosara de Resende (BRASIL, 2008, p. 37), “a igualdade perante a lei serve para que as diferenças advindas da deficiência năo sejam fatores e 
exclusâo ou de marginalizaçăo social, já que garante a participaçáo destas pessoas como parte da populaçăo". Neste desdobramento, o instituto da curatela sobre impactos significativos.

Como se sabe, estăo sujeitos à curatela os maiores incapazes. No entanto, segundo as alteraçôes promovidas pelo Estatuto, năo há mais maiores absolutamente incapazes. Assim, o instituto da curatela se volta exclusivamente para atender aqueles que, por causa transitória ou permanente, năo puderem exprimir sua vontade (por exemplo, uma pessoa em coma induzido ou os surdos-mudos cuja deficiência decorre de uma lesăo ou anormalidade mental grave), aos ébrios habituais e aos viciados em tóxico e os pródigos.

Embora as modificaçôes possam trazer avanços, ainda há muitas críticas e dúvidas sobre o manejo de situaçóes em concreto, seja pela ausência de normas de transiçăo, seja pelos atropelamentos legislativos causados. Segundo Madaleno (2016):

o critério adotado pelo Código Civil para que alguém possa ser declarado incapaz de reger seus bens por deficiência mental é de caráter biológico, porquanto a deficiência mental deve ser de tal gravidade, que seja possível afirmar que o enfermo năo governa sua própria conduta, constituindo-se em um estado ordinário de saúde, e năo um estado acidental.

No entanto, a curatela năo atinge mais os direitos pessoais.

José Fernando Simáo (2016) aponta que ao colocar aqueles que por causa transitória ou permanente, năo puderem exprimir sua vontade no rol dos relativamente incapazes oferece graves consequências. Em seu exemplo, o autor cita o caso de alguém estar em como induzido por questōes médicas, ficando temporariamente sem discernimento algum. Como será possível realizar atos da vida civil com assistência ou auxílio? Nesse caso, "a interdiçấo que, por fim, declarar a pessoa relativamente incapaz será inútil em termos fáticos, pois o incapaz năo poderá participar dos atos da vida civil" (SIMÂO, 2016), pois a mudança legislativa poderá prejudicar aos que necessitam de representaçâo e năo assistência para o exercício de atos da vida civil.

Maria Berenice Dias informa:

A tendência atual é dar maior liberdade ao curatelado, deixando-o praticar sozinho atos de natureza năo patrimonial, cujos efeitos se limitam à esfera existencial, como o caso do reconhecimento de paternidade. A proteçáo deve ocorrer na exata medida da ausência de discernimento, para que năo haja supressáo da autonomia, dos espaços de liberdade. As restriçóes à incapacidade de agir náo existem para alhear os incapazes, mas para integrá-los ao mundo estritamente negocial. Segundo Pìetro Perlingieri, é preciso privilegiar, sempre que possível, as escolhas da vida que o deficiente psíquico é capaz, concretamente, de exprimir, ou em relaçáo às quais manifesta notável propensấo. A disciplina da interdiçăo náo pode ser traduzida em uma incapacidade legal absoluta, em uma "morte civil". Permitir que o curatelado possa decidir, sozinho, questóes para as quais possui discernimento é uma forma de tutela da pessoa humana, pois a autonomia da vontade é essencial para o livre desenvolvimento da personalidade. A real necessidade da pessoa com algum tipo de doença mental é menos a substituiçáo na gestăo patrimonial e mais, como decorrência do princípio da solidariedade e da funçáo protetiva do curador, garantir a dignidade, a qualidade de vida, a recuperaçăo da saúde e a inserçăo social do interditado. Para quem dispóe de discernimento parcial, a interdiçăo deve ser limitada, relativa à prática de certos atos (CC 1.772 e 1.780), cabendo 
ao juiz delimitar sua extensăo (CC1.772). Nesses casos, há a sugestăo - mas năo a imposiçâo - de que as restriçôes sejam as mesmas previstas para os pródigos (CC 1.782). Como alerta Sérgio Girschkow Pereira, trata-se de curatela sem interdiçấo. [...] A curatela náo leva à incapacidade absoluta do curatelado. Cabe distinguir o grau de incapacidade. Desse modo, o curador representa o curatelado absolutamente incapaz e o assiste quando sua incapacidade é relativa (DIAS, 2015, pp. 687-688).

Pablo Stolze, em artigo lançado no ano de 2015, também observa algumas imprecisôes técnicas incorporadas na modificaçấo legislativa quando ainda permitiria a curatela (mesmo como medida de caráter excepcional) para pessoas com deficiência, que mesmo sendo capazes pela nova sistemática, poderiam ser consideradas como incapazes. Trata-se da figura dos capazes sob curatela. Qual a funçăo do curador nessas circunstâncias? A questâo é complexa. A possibilidade de por em curatela deficiente (pessoa capaz) está prevista no artigo 84, parágrafo primeiro da lei n.o 13.146/2015, que dispóe que "quando necessário, a pessoa com deficiência será submetida à curatela, conforme a lei". Trata-se das hipóteses em que a deficiência é severa, impossibilitando que o curatelado exerça atos da vida civil com autonomia da vontade.

Ao lado dessas questōes, Flávio Tartuce (2016) também indica outros problemas. Senâo, vejamos: segundo o autor, a lei n.․⒔146/2015 nâo trouxe a ideia de inter diçấo, mas sim de uma açăo judicial em que haverá a nomeaçăo de um curador. Por outro lado, o novo Código de Processo Civil náo regulou essa açáo judicial, e baseou-se apenas no processo de interdiçâo, conforme se observa a partir dos artigos 747 a 758.

De fato, o artigo 1768 do Código Civil foi alterado em pouco mais de três meses por duas vezes. A primeira alteraçăo efetiva ocorreu com a entrada em vigor do Estatuto da Pessoa com Deficiência em janeiro de 2016, que modificou o artigo deixando de mencionar que "a interdiçâo será promovida" e, depois, pelo NCPC (artigo 1072, II), que revogou expressamente o artigo 1768 do Código Civil a partir de março de 2016. Ao que tudo indica, a exclusăo do art. 1768 pode ter ocorrido para evitar que na legislaçâo sobre direito material houvesse disposiçáo sobre matéria de direito processual. No entanto, Paulo Lobo (2016) é mais assertivo ao afirmar:

O novo CPC desconsiderou tanto o projeto de lei que se converteu no Estatuto da Pessoa com Deficiência, quanto, o que é mais grave, a Convençáo promulgada em 2009, que tem força de emenda constitucional, [...], com supremacia sobre qualquer lei ordinária.

Tanto Paulo Lobo (2016) quanto Flávio Tartuce (2016) apontam que o espírito da Convençăo Internacional (com força de emenda constitucional) e do próprio Estatuto da Pessoa com Deficiência devem prevalecer, de modo a impor ao novo CPC interpretaçáo conforme à Constituiçáo.

A reforma produzida também impactou na ausência de năo ofertar previsăo a respeito das pessoas com desenvolvimento reduzido. É o caso da sociopatia ou psicopatia, que deixam de ser considerados absolutamente incapazes. A crítica de Tartuce (2016) é relevante, pois, infelizmente, o legislador pensou apenas na pessoa com deficiência, deixando de lado outras situaçôes concretas. Em referência a tais casos, Tartuce já apontava que desde 2014 havia previsâo nesse sentido, conforme destacou a jurisprudência do Superior Tribunal de Justiça que se transcreve a seguir: 
PROCESSUAL CIVIL. CIVIL.RECURSO ESPECIAL. INTERDIÇĂO. CURATELA. PSICOPATA. POSSIBILIDADE. 1. Açăo de interdiçăo ajuizada pelo recorrente em outubro de 2009. Agravo em recurso especial distribuído em 07/10/2011. Decisâo determinando a reautuaçâo do agravo em recurso especial publicada em 14/02/2012. Despacho determinando a realizaçấo de nova perícia psiquiátrica no recorrido publicado em 18/12/2012. 2. Recurso especial no qual se discute se pessoa que praticou atos infracionais equivalentes aos crimes tipificados no art. $121, \S 2^{\circ}$, II, III e IV (homicídios triplamente qualificados), dos quais foram vítimas o padrasto, a măe de criaçăo e seu irmáo de 03 (três) anos de idade, e que ostenta condiçấo psiquiátrica descrita como transtorno năo especificado da personalidade (CID 10 - F 60.9), está sujeito à curatela, em processo de interdiçáo promovido pelo Ministério Público Estadual. 3. A reincidência criminal, prevista pela psiquiatria forense para as hipóteses de sociopatia, é o cerne do presente debate, que náo reflete apenas a situaçăo do interditando, mas de todos aqueles que, diagnosticados como sociopatas, já cometeram crimes violentos. 4. A psicopatia está na zona fronteiriça entre a sanidade mental e a loucura, onde os instrumentos legais disponíveis mostram-se ineficientes, tanto para a proteçăo social como a própria garantia de vida digna aos sociopatas, razăo pela qual deve ser buscar alternativas, dentro do arcabouço legal para, de um lado, náo vulnerar as liberdades e direitos constitucionalmente assegurados a todos e, de outro turno, năo deixar a sociedade refém de pessoas, hoje, incontroláveis nas suas açóes, que tendem à recorrência criminosa. 5. Tanto na hipótese do apenamento quanto na medida socioeducativa - ontologicamente distintas, mas intrinsecamente iguais - a repressăo do Estado traduzida no encarceramento ou na internaçăo dos sociopatas criminosos, apenas postergam a questăo quanto à exposiçăo da sociedade e do próprio sociopata à violência produzida por ele mesmo, que provavelmente, em algum outro momento, será replicada, pois na atual evoluçaáo das ciências médicas năo há controle medicamentoso ou terapêutico para essas pessoas. 6. A possibilidade de interdiçăo de sociopatas que já cometeram crimes violentos deve ser analisada sob o mesmo enfoque que a legislaçăo dá à possibilidade de interdiçăo - ainda que parcial - dos deficientes mentais, ébrios habituais e os viciados em tóxicos (art. 1767, III, do CC-02). 7. Em todas essas situaçóes o indivíduo tem sua capacidade civil crispada, de maneira súbita e incontrolável, com riscos para si, que extrapolam o universo da patrimonialidade, e que podem atingir até a sua própria integridade física sendo também ratio năo expressa, desse excerto legal, a segurança do grupo social, mormente na hipótese de reconhecida violência daqueles acometidos por uma das hipóteses anteriormente descritas, tanto assim, que náo raras vezes, sucede à interdiçâao, pedido de internaçăo compulsória. 8. Com igual motivaçăo, a medida da capacidade civil, em hipóteses excepcionais, năo pode ser ditada apenas pela mediana capacidade de realizar os atos da vida civil, mas, antes disso, deve ela ser aferida pelo risco existente nos estados crepusculares de qualquer natureza, do interditando, onde é possível se avaliar, com precisăo, o potencial de autolesividade ou de agressâo aos valores sociais que o indivíduo pode manifestar, para daí se extrair sua capacidade de gerir a própria vida, isto porquê, a mente psicótica náo pendula entre sanidade e demência, mas há perenidade etiológica nas açôes do sociopata. 9. A apreciaçâo da possibilidade de interdiçăo civil, quando diz respeito à sociopatas, pede, entáo, medida inovadora, açăo biaxial, com um eixo refletindo os interesses do interditando, suas possibilidades de inserçấo social e o respeito à sua dignidade pessoal, e outro com foco no coletivo - ditado pelo interesse mais primário de um grupo social: a proteçáo de seus componentes -, linhas que devem se entrelaçar para, na sua síntese, dizer sobre o necessário discernimento para os atos da vida civil de um sociopata que já cometeu atos de agressăo que, in casu, levaram a óbito três pessoas. 10. A soluçấo 
da querela, entăo, náo vem com a completa abstraçăo da análise da capacidade de discernimento do indivíduo, mas pela superposiçâo a essa camada imediata da norma, da mediata proteçăo do próprio indivíduo e do grupo social no qual está inserido, posicionamento que encontrará, inevitavelmente, como indivíduo passível de interdiçăo, o sociopata que já cometeu crime hediondo, pois aqui, as brumas da dúvida quanto à existência da patologia foram dissipadas pela violência já perpetrada pelo indivíduo. 11. Sob esse eito, a sociopatia, quando há prévia manifestaçáo de violência por parte do sociopata, demonstra, inelutavelmente, percepçáo desvirtuada das regras sociais, dos limites individuais e da dor e sofrimento alheio, condiçóes que apesar de náo infirmarem, per se, a capacidade do indivíduo gerenciar sua vida civil, por colocarem em cheque a própria vida do interditando e de outrem, autorizam a sua curatela para que ele possa ter efetivo acompanhamento psiquiátrico, de forma voluntária ou coercitiva, com ou sem restriçôes à liberdade, a depender do quadro mental constatado, da evoluçâo - se houver - da patologia, ou de seu tratamento. 12. Recurso especial provido.

Essas situaçôes estăo sendo refletidas em inúmeras decisôes judiciais e nâo necessariamente nas instâncias legislativas. Há situaçōes em que a extensăo da incapacidade, quando existente, deve ser avaliada em sua plenitude, pois um deficiente psíquico pode náo ser totalmente incapaz para as amplas situaçóes em que atos da vida civil podem ser praticados. Como esclarece Madaleno (2016) ao citar María Victória Famá, Marisa Herrera e Luiz María Pagano:

toda limitaçáo à capacidade supóe uma limitaçâo à liberdade pessoal, e a inclusăo do sujeito entre os que detêm personalidade psicótica só deve ser admitida quando o desequilíbrio psíquico - náo mórbido - for acentuado, grave e acarrete fundado perigo para sua subsistência, com capacidade da pessoa produzir dano a si e ao seu patrimônio.

A seguir, passa-se a analisar o instituto da tomada de decisâo apoiada.

No Brasil, a tomada de decisáo apoiada é um instituto que possui desdobramento imediato da Convençăo sobre Direitos das Pessoas com Deficiência e da Lei de Inclusâo da Pessoa com Deficiência. Com a inclusâo do instituto no Código Civil, sua disciplina flui a partir do art. 1.783-A.

Pela definiçâo legal, a tomada de decisâo apoiada é o processo pelo qual a pessoa com deficiência elege pelo menos duas pessoas idôneas, com as quais mantenha vínculos e que gozem de sua confiança, para prestar-lhe apoio na tomada de decisâo sobre atos da vida civil, fornecendo-lhes os elementos e informaçóes necessárias para que possa exercer sua capacidade.

Como se pode observar, o procedimento visa criar alternativas para que as pessoas com deficiência possam exercer pessoalmente atos da vida civil com maior autonomia, na proporçâo de suas necessidades. No artigo 12 da Convençăo Internacional há o pleno reconhecimento da igualdade perante a lei e, assim, o modelo de tomada de decisăo assistida é uma forma de evitar que a vontade da pessoa interdidata seja substituída pela vontade do curador.

O Brasil nâo é pioneiro ao adotar essas medidas de inclusâo após considerar pessoas com deficiência plenamente capazes para atuar nos atos da vida civil. Cleide Ramos, em comentário ao artigo 12 da Convençâo sobre os Direitos das Pessoas com Deficiência, aponta que: 
Na Suécia já se adota um modelo altamente capacitante, tendo a pessoa do curador a incumbência de auxiliar a pessoa com deficiência a fazer escolhas e tomar decisôes de forma independente. Essa figura, chamada de ombudsperson, năo é indicada num processo judicial de interdiçấo, fazendo parte dos quadros da Administraçăo Pública, com a incumbência de se aproximar da pessoa com deficiência, conquistar sua confiança, o que pode levar dias, meses ou anos, e por fim auxiliá-la a manifestar a sua vontade sobre aspectos da sua vida, ou táo somente prestar apoio em momentos difíceis (BRASIL, 2008, p. 55).

No direito italiano, registra Gaburri (2016), desde 2004, também há a figura do amministrazione di sostegno (administrador de apoio, em traduçâo livre). 0 artigo 404 do Código Civil italiano dispôe:

a pessoa que, devido uma doença ou uma deficiência física ou mental, se torna impossibilitado, ainda que parcial ou temporário, para atender seus interesses, pode ser assistido por um administrador de apoio, designando o magistrado o local em que tenha residência ou domicílio. [traduçâo livre].

Madaleno (2016) e Gaburri (2016) fazem referência ainda à Argentina, que em 2016, contemplou o Sistemas de Apoyo al Ejercício de la Capacidad. No artigo 43 do Código Ciivl argentino dispóe:

Concepto. Función. Designación. Se entiende por apoyo cualquier medida de carácter judicial o extrajudicial que facilite a la persona que lo necesite la toma de decisiones para dirigir su persona, administrar sus bienes y celebrar actos jurídicos en general. Las medidas de apoyo tienen como función la de promover la autonomía y facilitar la comunicación, la comprensión y la manifestación de voluntad de la persona para el ejercicio de sus derechos. El interesado puede proponer al juez la designación de una o más personas de su confianza para que le presten apoyo. El juez debe evaluar los alcances de la designación y procurar la protección de la persona respecto de eventuales conflictos de intereses o influencia indebida. La resolución debe establecer la condición y la calidad de las medidas de apoyo y, de ser necesario, ser inscripta en el Registro de Estado Civil y Capacidad de las Personas.

No direito argentino e português, noticia Rolf Madaleno que há uma:

[...] diferença entre incapacidade e inabilitaçăo, ocorrendo esta última quando náo é a razáo ou o discernimento da pessoa que se encontram afetados, mas sua vontade é que se encontra comprometida, como no exemplo do pródigo, do surdo-mudo, do cego, ou daquele que abusa de bebidas alcóolicas ou de estupefacientes, e estas circunstâncias os tornam incapazes de reger convenientemente o seu patrimônio, sendo promovida a declaraçăo judicial de sua inabilitaçăo em processo similar ao de interdiçâo por incapacidade, sendo distintos os efeitos jurídicos da sentença já que a ingerência da curatela é eminentemente patrimonial (MADALENO, 2016). (grifo do autor)

No caso brasileiro, o foco da tomada de decisáo apoiada é reconhecer que muitas vezes o pessoa com deficiência năo precisa de um substituto, mas sim de um apoio qualificado frente suas capacidades e na eliminaçăo dos obstáculos do meio para promover o exercício de direitos pessoalmente com inclusăo.

Para formular o pedido, a pessoa com deficiência e os apoiadores devem apresentar termo em que constem os limites do apoio oferecido e os compromissos dos apoiadores. A indicaçăo de prazo de vigência do acordo e respeito à vontade, aos direitos 
e interesses da pessoa que devem apoiar também devem ser apresentados, conforme dispóe o parágrafo primeiro do artigo 1.783-A, do Código Civil.

A legitimidade do pedido se conforma com a própria açâo do beneficiário do apoio que pode solicitar ao juiz o pedido. Os demais dispositivos do artigo 1.783-A dispóe que: Antes de se pronunciar sobre o pedido de tomada de decisâo apoiada, o juiz, assistido por equipe multidisciplinar, após oitiva do Ministério Público, ouvirá pessoalmente o requerente e as pessoas que lhe prestarâo apoio $\left(\S 3 .^{\circ}\right)$; A decisâo tomada por pessoa apoiada terá validade e efeitos sobre terceiros, sem restriçōes, desde que esteja inserida nos limites do apoio acordado. (§ 4. $\left.{ }^{\circ}\right)$; Terceiro com quem a pessoa apoiada mantenha relaçấo negocial pode solicitar que os apoiadores contra-assinem o contrato ou acordo, especificando, por escrito, sua funçăo em relaçăo ao apoiado (§ 5. ${ }^{\circ}$ ); Em caso de negócio jurídico que possa trazer risco ou prejuízo relevante, havendo divergência de opiniōes entre a pessoa apoiada e um dos apoiadores, deverá o juiz, ouvido o Ministério Público, decidir sobre a questăo $\left(\S 6^{\circ}{ }^{\circ}\right)$; Se o apoiador agir com negligência, exercer pressáo indevida ou năo adimplir as obrigaçôes assumidas, poderá a pessoa apoiada ou qualquer pessoa apresentar denúncia ao Ministério Público ou ao juiz. (§ 7.॰); Se procedente a denúncia, o juiz destituirá o apoiador e nomeará, ouvida a pessoa apoiada e se for de seu interesse, outra pessoa para prestaçăo de apoio $\left(\S 8 .^{\circ}\right)$; A pessoa apoiada pode, a qualquer tempo, solicitar o término de acordo firmado em processo de tomada de decisâo apoiada (§ 9.๑); O apoiador pode solicitar ao juiz a exclusăo de sua participaçấo do processo de tomada de decisâo apoiada, sendo seu desligamento condicionado à manifestaçăo do juiz sobre a matéria (§ 10) e aplicam-se à tomada de decisâo apoiada, no que couber, as disposiçóes referentes a prestaçáo de contas na curatela ( $\$ 11)$.

Na prática, o instituto permite a inclusăo de inúmeras pessoas com deficiência para amplos exercícios de atos da vida civil. Alinha-se com a Convençâo sobre as Pessoas com Deficiência e estabelece um novo marco para o exercício de direitos.

\section{CONSIDERAÇÕES FINAIS}

As açôes da Organizaçâo das Naçôes Unidas (ONU) para promover, proteger e assegurar em igualdade de condiçóes o exercício pessoal de direitos para as pessoas com deficiência, em 2006, vieram em boa hora. Apenas em 2015, com a Lei de Inclusâo da Pessoa com Deficiência, houveram alteraçôes significativas na legislaçâo infraconstitucional brasileira para colocar em vigor medidas que pudessem oportunizar às pessoas com deficiência o exercício de direitos.

Ao modificarem a teoria da incapacidade absoluta, com exclusăo dos deficientes desta modalidade, a lei modificou os institutos da curatela e proporcionou o exercício inédito de direitos a partir do instituto da tomada de decisâo apoiada.

Nesse processo, um dos grandes destaques é que a legislaçâo estabeleceu que a deficiência năo deve ser um atributo da pessoa, como uma condiçáo estática e biológica da pessoa. Ao compreender que o conceito de deficiência está em constante evoluçấo, a lei póe em destaque o impedimento, de natureza física, mental, intelectual ou sensorial como resultado de interaçóes das barreiras existentes que possam obstruir sua participaçăo plena e efetiva na sociedade em igualdade de condiçóes com as demais pessoas. 
Na primeira parte do trabalho, buscou-se demonstrar como a lei de inclusăo da pessoa com deficiência reflete uma política internacional de inclusăo. Na segunda parte, destacou-se os desafios criados pelo Estatuto da Pessoa com Deficiência com a teoria da incapacidade civil para construir o instituto da Tomada de Decisăo Apoiada.

Em sede de consideraçôes finais, constatou-se que a ausência de normas de transiçấo entre as legislaçôes materiais e processuais podem causar uma série de problemas para o manejo de direitos das pessoas com deficiência, pois modificam institutos sem resguardá-los ou integra-los a situaçōes inéditas.

Em relaçáo a curatela, a possibilidade de coexistir com pessoas capazes (deficientes) pode transparecer uma atecnia desnecessária, mas que devem ser tratadas na perspectiva da lei $n \cdot-13.146 / 2015$. Com as alteraçóes, as pessoas com deficiência que estivessem sob curatela após a vigência da lei de inclusăo, tem como alternativa suscitarem o pedido de levantamento da curatela, de modo a compatibilizar a nova condiçáo de capacidade.

A pessoa com deficiência deve ser apoiada para exercer sua capacidade civil. Como pontua Cleide Ramos, "a incapacidade depende do meio em que vive a pessoa, seja por influência de seus condicionantes sociais, econômicos ou ambientais ou mesmo pelos seus condicionantes culturais, dos quais se destaca o estigma e o preconceito incapacitante" (BRASIL, 2008, p. 57). Cabe à sociedade, ao lado do Estado, um papel essencial neste processo: evitar a que invisibilidade social continue a naturalizar a exclusăo das pessoas com deficiência. 


\section{REFERÊNCIAS BIBLIOGRÁFICAS}

ARGENTINA. Código Civil y Comercial de la Nación. Cuidad Autónoma de Buenos Aires: Infojus, 2014.

BRASIL. A convençăo sobre direitos das pessoas com deficiência comentada. RESENDE, Ana Paula Crosara; VITAL, Flávia Maria de Paiva. (Coords.). Brasília: Secretaria Especial dos Direitos Humanos; Coordenadoria Nacional para Integraçăo da Pessoa Portadora de Deficiência, 2008.

. Decreto n. ${ }^{\circ}$ 6.949/2009. Dispôe sobre a Convençâo Internacional sobre os Direitos das Pessoas com Deficiência. Disponível em: <http://www.planalto.gov.br/ccivil 03/_ Ato2007-2010/2009/Decreto/D6949.htm>. Acesso em: 06 dez. 2016.

. Lei n. ${ }^{\circ}$ 13.146/2015. Institui a Lei Brasileira de Inclusāo da Pessoa com Deficiência. Disponível em: <http://www.planalto.gov.br/ccivil_03/_Ato2015-2018/2015/Lei/L13 146.htm\#art114>. Acesso em: 06 .dez. 2016.

. Lei n. ${ }^{\circ}$ 10.406/2002. Institui o Código Civil brasileiro. Disponível em: <http://www. planalto.gov.br/ccivil_03/leis/2002/L10406.htm>. Acesso em: 06 dez. 2016.

. Projeto de Lei n. ${ }^{\circ}$ 7.699/2006. Institui o Estatuto do Portador de Deficiência e dá outras providências. Disponível em: <http://www.camara.gov.br/proposicoesWeb/fichadetramitacao?idProposicao=339407>. Acesso em: 06 dez. 2016.

DIAS, Maria Berenice. Manual de Direito das Famílias. Revista dos Tribunais, Săo Paulo, 2015.

GABURRI, Fernando. Capacidade e tomada de decisăo apoiada: implicaçōes do Estatuto da Pessoa com Deficiência no Direito Civil. Revista Direito e Desenvolvimento, Joâo Pessoa, v. 7, n. 13. pp. 118-135, 2016.

LOBO, Paulo. Com avanços legais, pessoas com deficiência mental nâo sâo mais incapazes. Conjur, 16 ago. 2015. Disponível em: <http://www.conjur.com.br/2015-ago-16/ processo-familiar-avancos-pessoas-deficiencia-mental-nao-sao-incapazes〉. Acesso em: 10 dez. 2016.

MADALENO, Rolf. Direito de Família. 7. ed. Rio de Janeiro: Forense, 2016.

SIMĀO, José Fernando. Estatuto da Pessoa com Deficiência causa perplexidade (Parte 2). Conjur, 7 de agosto de 2015. Disponível em: <http://www.conjur.com.br/2015-ago-07/ jose-simao-estatuto-pessoa-deficiencia-traz-mudancas>. Acesso em: 13 dez. 2016.

STOLZE, Pablo. 0 Estatuto da Pessoa com Deficiência e o sistema jurídico brasileiro de incapacidade civil. JusNavigandi, julho.2015. Disponível em: <https://jus.com.br/ artigos/41381/o-estatuto-da-pessoa-com-deficiencia-e-o-sistema-juridico-brasileirode-incapacidade-civil>. Acesso em: 10 out. 2015.

TARTUCE, Flávio. Direito de Família. 11. ed. Rio de Janeiro: Forense, 2016. v. 5

RECEBIDO EM: 01/01/2017

APROVADO EM: 16/04/2017 